\title{
INFORMATION AS THE BASIS FOR THE DIFFERENTIATION OF THE SUBJECT AND OBJECTS OF FORENSIC EXAMINATIONS
}

\author{
Shcherbakovskiy M. G.
}

The subject of forensic examination as a practical activity is one of the most important categories of forensic examinations theory. The subject of forensic examination is used to classify forensic examinations. The definition of the subject of forensic examinations through the prism of information theory categories is the most productive. Information is a part of the data about the investigated object which is used to solve a particular task. Legal information is used during investigation of crimes. The author proposes a classification of legal information. Information is divided into criminally relevant and neutral, depending on the relationship of the data to the event of the crime. Information is procedural or nonprocedural, depending on the method of receipt in accordance with the procedural law. Information is evidentiary if it presents the content of evidence by itself. Information is orienting when it's used for organizational or tactical purposes. Information is criminalistic, expert or operative-search, depending on the methods and subjects of its receipt. Information, received by the expert during the investigation, is criminally relevant or neutral, procedural, expert, evidentiary or orienting. The data that are received by an expert, become useful information if they help to resolve issues put to a forensic expert. A special object of forensic examination (information field) is the totality of homogeneous properties of the subsumer. The direct object of an expert research is a part of a special object that is subjected to research during a specific expert study. The subject of forensic examination kind is evidentiary and orienting information that can be obtained at the contemporary stage of forensic examination development by researching a special object that is a part of the object properties of forensic examination kind. The subject of particular forensic examination is evidentiary or orienting information, which must be obtained by an investigation of a direct object that is the part of the properties of the particular material carrier submitted for examination.

Keywords: forensic examination, legal information, special and direct objects of forensic research, subject of the kind and particular forensic examination. ного бюро экспертиз Республики Армения, кандидат медицинских наук, П. С. Восканян, заместитель директора Национального бюро экспертиз Республики Армения, кандидат химических наук, старший научный сотрудник

\section{О ДОПОЛНИТЕЛЬНОЙ ПРОФЕССИОНАЛЬНОЙ ПОДГОТОВКЕ ПО ЭКСПЕРТНЫМ СПЕЦИАЛЬНОСТЯМ В НАЦИОНАЛЬНОМ БЮРО ЭКСПЕРТИЗ}

Представлено положение о дополнительной профессиональной подготовке по экспертным специальностям, разработанное в Национальном бюро экспертиз Республики Армения и реализуемое на практике. Отмечено, 
что разработанные единые подходы к подготовке судебных экспертов разных специализачий в рамках индивидуальных кратко- и среднесрочных курсов позволяют обеспечить требуемый уровень профессиональной подготовки с последующей аттестацией соискателей на право самостоятельного производства судебных экспертиз. Показано, что опираясь на критерии, заложенные в действующее положение, с 2005 года по настоящее время свыше 300 соискателей прошли иикл дополнительного образования и получили соответствующие свидетельства.

Ключевые слова: судебный эксперт, дополнительное профессиональное образование, порядок организации образовательной деятельности, учебные модули.

Кардинальные изменения в государственном устройстве Республики Армения (РА), связанные с демократизацией общества и его государственных институтов, сказались и на необходимости обеспечения объективности доказательной базы, основанной на непредвзятом исследовании всех допустимых доказательств, полученных в рамках уголовного судопроизводства. Одним из шагов в этом направлении стало создание в 2004 г. в соответствии с постановлением Правительства РА № 1127-Н Национального бюро экспертиз и функционирование его в качестве самостоятельного независимого учреждения.

Развитие в республике экспертно-криминалистической службы в свою очередь потребовало обеспечить необходимость подготовки высококвалифицированных экспертных кадров. К сожалению, в РА отсутствовала практика целевой подготовки судебных экспертов высшими учебными заведениями. С целью восполнения этого пробела распоряжением Президента Национальной академии наук Республики Армения (НАН РА) № 38 от 29 августа 2005 г. в структуре НАН РА была создана квалификационная комиссия судебных экспертов. Руководствуясь требованиями п. 2.1 Положения о порядке сертификации судебных экспертов в структуре Национальной академии наук Республики Армения, соответствующим распоряжением Президента НАН РА также был утвержден состав квалификационной комиссии судебных экспертов. Таким образом, начиная с 2005 года в НАН РА, в рамках научно-образовательной деятельности стала осуществляться программа подготовки и повышения квалификации специалистов в области экспертологии (криминалистики), а также в соответствии с законодательством РА, их квалификационное освидетельствование.

Важно отметить, что классификация экспертиз предопределила подготовку и переподготовку экспертных кадров, поскольку в предоставляемом судебному эксперту свидетельстве о праве на производство экспертизы должен быть четко зафиксирован вид разрешаемой экспертизы ${ }^{1}$.

\footnotetext{
1 Хрусталев B. Н. Опыт подготовки экспертов-криминалистов (по материалам зарубежной печати). Экспертная практика. 1995. № 38. С. 38; Россинская Е. Р. Проблемы развития новых судебных экспертиз и подготовки экспертных кадров. Закон. 2005. № 6. С. 100-105; Енгальччев В. Ф. О подготовке экспертов-психологов в Калужском государственном педагогическом университете им. К. Э. Циолковского. Теория
} 
Благодаря упомянутой программе соискателю на получение специальности в той или иной области экспертологии предоставляется возможность ознакомиться с квалификационными требованиями, предъявляемыми к профессиональным знаниям и навыкам, необходимым судебному эксперту соответствующей специальности, изучить принципы, методы, методики, технологии, используемые при производстве экспертных исследований, а также получить специальную информацию об актуальных задачах правового регулирования данной области.

Отметим, что при разработке программы по реализации дополнительного профессионального образования по подготовке квалифицированных судебных экспертов был учтен и обобщен международный практический опыт, в частности США, ведущих европейских стран, России, а также действующие в экспертных организациях упомянутых стран методы и процедуры дополнительного образования ${ }^{1}$.

Подчеркнем, что на первой стадии был разработан документ, в котором четко были прописаны виды и подвиды осуществляемых в РА судебных экспертиз. Необходимо отметить, что этот документ подлежит пересмотру раз в 5 лет, исходя из соображений возникновения и развития новых видов и подвидов экспертиз. При этом действующим и планирующимся в последующем тем или иным видам и подвидам судебных экспертиз соответствуют четкие экспертные специальности, имеющие определенные названия и квалификационные характеристики. Также предварительно был уточнен

и практика судеб. экспертизы. 2008. № 4(12). С. 54-57; Черных Н. А., Омельянюк Г. Г., Усов А. И. Перспективы подготовки экспертов в области судебно-экологической экспертизы в Российском университете дружбы народов. Вестник Pос. ун-та дружбы народов. Серия: Экология и безопасность жизнедеятельности. 2007. № 2. C. 75-80; Шкоропат E. A., Задоров A. Г. Практическая направленность учебного процесса необходимое условие подготовки судебных экспертов в системе высшего профессионального образования. Вестник Волгоград. акад. МВД России. 2008. № 2(7). С. 109-112; Хрусталев В. Н. Перспективы академической подготовки судебных экспертов в России. Эксперт-криминалист. 2013. № 1. С. 20-22.

1 Сейтенов $K . K$. Международный форум по судебной экспертизе в КАЗГЮУ. Право и государство. 2016. № 1(70). С. 6-11; Аминев Ф. Г. О некоторых актуальных проблемах профессиональной подготовки судебных экспертов. Судебная экспертиза: российский и международный опыт: материалы Междунар. науч.-практ. конф. 2012. С. 441-446; Усов А. И. Современные модели обучения судебных экспертов как основа кадрового обеспечения судебно-экспертной деятельности в Евразийском экономическом союзе. Теория и практика судебной экспертизы. 2015. № 4(40). C. 20-25; Положение о дополнительном профессиональном образовании работников федеральных бюджетных судебно-экспертных учреждений Министерства юстиции Российской Федерации. URL: http//www.sudexpert.ru/files/norms/239.doc (дата обращения:16.12.2014); Смирнова С. А. Проблемы профессиональной подготовки судебных экспертов. Теория и практика судеб. экспертизы. 2013. № 2(30). С. 24-27;

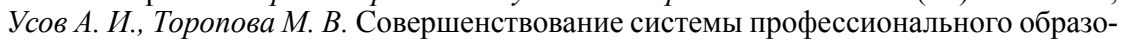
вания государственных судебных экспертов. Там же. 2015. № 1(37). С. 34-39; Россинская E. P. Федеральные государственные образовательные стандарты 3-го поколения и подготовка судебно-экспертных кадров в России. Право и государство. 2016. № 1(70). C. 12-15. 
перечень имеющихся в РА высших учебных заведений и специальностей, последние были сопоставлены с соответствующими экспертными профессиями. Например, документоведческий вид экспертных исследований, его подвид - техника и способ подготовки документов, требует, чтобы соискатель на должность эксперта имел знания, как минимум, по следующим специальностям: физика, химия, редакторское дело, полиграфия и т. п., т. е. имел бы высшее базовое образование (степень магистра или дипломированного специалиста), соответствующее требованиям дополнительной профессиональной программы по экспертной специальности, по которой планируется обучение.

Важно отметить, что к обучению по программе дополнительного профессионального образования принимаются физические лица - граждане PA, имеющие высшее образование (со степенью магистра или дипломированного специалиста), соответствующее требованиям дополнительной профессиональной программы по экспертной специальности, по которой планируется обучение. В рамках действующей в Национальном бюро экспертиз программы, зачисляемое на обучение физическое лицо по конкретной дополнительной профессиональной программе по экспертной специальности проходит полный курс обучения и подготовки. Особенность этой модели дополнительного профессионального образования состоит в том, что на первом этапе соискателю методом генерации случайных чисел предъявляются в электронном варианте в виде тестов 100 из 1000-1500 специальных вопросов, предварительно подготовленных в Национальном бюро экспертиз с целью проверки базовых знаний соискателя. В случае удовлетворительной оценки, полученной в результате тестирования, т. е. преодоление определенного порога, физическое лицо, претендующее на получение квалификации судебного эксперта, проходит устное собеседование, после чего в рамках договора об оказании платных образовательных услуг производится зачисление соискателя, для которого разрабатывается программа дополнительной профессиональной подготовки по экспертной специальности, состоящая из теоретической и практической частей. Срок обучения по этой программе устанавливается от 3 до 9 месяцев и зависит от уровня базовой подготовки слушателя и объема осваиваемой программы, а в отдельных случаях, как показывает многолетний опыт подготовки судебных экспертов, для некоторых специальностей может затянуться и составить более 9-ти месяцев. Необходимо иметь в виду, что вне зависимости от экспертных направлений, все соискатели в обязательном порядке проходят также теоретический курс по судебно-правовому регулированию вопросов, касающихся назначения и проведения экспертиз. Прохождение этого курса позволяет соискателю познать как основы законодательства о судебной экспертизе, так и основы общей и частных теорий судебной экспертизы.

Важно подчеркнуть, что в последние три года в профессиональную образовательную программу дополнительно введены такие актуальные новые учебные модули, как тайм-менеджмент, позволяющий научиться правильно 
планировать свое время и стресс-менеджмент, позволяющий минимизировать влияние на человека стрессового воздействия ${ }^{1}$.

Обучение по программе получения дополнительного профессионального образования осуществляется под руководством наставника. Наставник назначается из числа высококвалифицированных судебных экспертов, имеющих право самостоятельного производства экспертиз по экспертной специальности, соответствующей программе дополнительного профессионального образования слушателя. При этом наставник составляет индивидуальный календарный учебный график соискателя, периодически осуществляет устный опрос по освоенным соискателем темам, контролирует выполнение практических работ, контрольных заданий и информирует отдел повышения квалификации Национального бюро экспертиз о ходе образовательного процесса соискателя.

По завершении программы подготовки соискатель на должность эксперта вновь проходит профессиональное тестирование, после чего кандидатура соискателя представляется на заседании Квалификационной комиссии Национального бюро экспертиз с сопроводительными материалами, содержащими мнение и заключение наставника, составленные на основе тематического реферата и краткого отчета соискателя о приобретенных за время обучения знаниях, с целью получения свидетельства, допускающего его к проведению судебных экспертиз по той или иной экспертной специальности. В заключении наставника также в обязательном порядке указывается уровень приобретенных знаний и профессиональных навыков соискателя, касающихся способов и подходов практического применения методик и технологий при производстве судебных экспертиз, навыков по определению основных проблем эксперта в области применения норм процессуального законодательства.

В подтверждение отметим, что с 2005 г. по настоящее время 324 соискателя на должность судебного эксперта успешно прошли цикл дополнительного профессионального образования с последующим получением свидетельств, позволяющих выполнять судебные экспертизы по соответствующим экспертным направлениям.

Формат статьи не позволяет подробно описать объем последовательных работ, систематически осуществляемых в Национальном бюро экспертиз по направлению присвоения квалификации судебного эксперта специалистам высшей категории. Однако в дополнение к сказанному отметим, что за последние 10 лет в Национальном бюро экспертиз накоплен большой

1 Брайан Т. Тайм-менеджмент. М.: Изд-во Манн, Иванов и Фербер. 2015. 144 с.; Моргенстерн Д. Тайм-менеджмент. Искусство планирования и управления своим временен и своей жизнью. Николаев: Добрая книга. 2013. 258 с.; Мрочковский Н., Толкачев А. Экстремальный тайм-менеджмент. М.: Альпина Паблишер. 2015. 214 с.; Каменюкин А. Г., Ковпак Д. В. Стресс-менеджмент. СПб.: Питер. 2012. 208 с.; Льюис Д. Управление стрессом: Как найти дополнительные 10 часов в неделю. М.: Альпина Паблишер. 2012. 238 с.; Сивил Д. Стресс-менеджмент. М.: Гиппо. 2006. $126 \mathrm{c}$. 
опыт в рамках научно-практических работ по обеспечению непрерывного обучения сотрудников организации, выполняющих судебные экспертизы, в частности, по вопросам приобретения новых экспертных профессий и принципов проверки знаний в подобных случаях, по определению критериев, необходимых для предоставления эксперту самостоятельности, сроков и длительности испытательного периода его деятельности, а также критериев оценки этой деятельности.

\section{ПРО ДОДАТКОВУ ПРОФЕСІЙНУ ПІДГОТОВКУ ЗА ЕКСПЕРТНИМИ СПЕЦІАЛЬНОСТЯМИ В НАЦІОНАЛЬНОМУ БЮРО ЕКСПЕРТИЗ}

\section{Джкавадян А.С., Восканян П. С.}

Наведено положення про додаткову професійну підготовку за експертними спеціальностями, розроблене в Національному бюро експертиз Республіки Вірменія та реалізуєме на практииі. Відзначено, щзо розроблені єдині підходи до підготовки судових експертів різних спеціалізацій у рамках індивідуальних коротко- $і$ середньострокових курсів дозволяють забезпечити необхідний рівень професійної підготовки з наступною атестацією здобувача на право самостійного проведення судових експертиз. Показано, щзо спираючись на критерії, закладені в чинне положення, з 2005 р. до сьогодні понад 300 здобувачів пройшли циикл додаткової освіти та одержали відповідні свідочтва.

Ключові слова: судовий експерт, додаткова професійна освіта, порядок організації освітньої діяльності, навчальні модулі.

\section{ON ADDITIONAL PROFESSIONAL TRAINING IN EXPERT SPECIALTIES IN THE NATIONAL BUREAU OF EXPERTISES}

\section{Javadyan A. S., Voskanyan P. S.}

The paper is devoted to the Regulation on Additional Professional Training in Expert Specialties developed by the National Bureau of Expertises of the Republic of Armenia and realized in practice. It's noted that the unified approaches, set forth in the Regulation, to the retraining of forensic experts of different specializations within the framework of individual short-and medium-term courses make it possible to provide the required level of professional training with the subsequent certification of the applicant for the right to independently perform a forensic examination. The peculiarities of the current model of additional professional education are described, including testing the basic knowledge of the applicant at the first stage, and in case of satisfactory evaluation, after an oral interview, training on the developed individual program consisting of theoretical and practical parts. Upon completion of the training program, the accompanying materials on the applicant's candidature are submitted to the meeting of the Qualification Commission established by the National Bureau of Expertises, which gives the right to the applicant to carry out independent forensic examination in one or another expert specialty (since 2005 in this manner more than 300 applicants it's prepared). The paper also emphasizes that the programs of additional professional training are periodically revised, supplemented with introducing new relevant training modules into the programs. In particular, the paper contains links to the introduction of modules such as time management and stress manage- 
ment into the educational process. The paper also highlights the accumulated experience allowing to provide a qualitative level of experts continuous training of the National Bureau of Expertises, particularly, on definition of the criteria necessary for granting independence to the expert, terms and duration of the probation period of his activity, criteria for evaluating this activity.

Keywords: forensic expert, additional professional education, procedure of educational activity organization, educational modules.

УДК 343.98

Е. Б. Сімакова-Сфремян, заступник директора Харківського НДІСЕ, кандидат юридичних наук, старший науковий співробітник

\section{ДО ПИТАННЯ ВЗАСМОЗАЛЕЖНОСТІ ЄВРОПЕЙСЬКИХ ІНТЕГРАЦІЙНИХ ПРОЦЕСІВ І ТЕНДЕНЦІЙ ІНТЕГРАЦІЇ СПЕЦАЛЬНИХ ЗНАНЬ В УКРАЇНІ}

Досліджено окремі питання глобалізачї світу та ї̈ впливу на європейські інтеграційні процеси, а також на тенденції інтеграції спеціальних знань у судовій експертизі. Проаналізовано порівняльний огляд європейських експертів в аспекті діяльності органів судової експертизи в Украйні та державах - членах СС. Визначено шляхи реалізаиї украӥнськими криміналістами й судовими експертами положень основних європейських документів, щуо визначають мінімальні стандарти та пропонують різні варіанти діяльності в галузі судової експертизи.

Ключові слова: світова глобалізачія, європейська інтеграчія, судовий експерт, законодавство про судову експертизу, інтеграція спеціальних знань.

В умовах світової глобалізації все більше зростає взаємозалежність країн світу, перетворення їх на єдиний глобальний організм, якому притаманні власні закони й тенденції розвитку. Глобалізація як будь-яке складне та багатоаспектне явище має певні наслідки, які суттєво впливають на історичні долі цілих народів на всіх континентах. Не оминає глобалізація й питання розвитку права і юридичних наук. Своєрідним підтвердженням цього є проведення Першого Харківського міжнародного юридичного форуму «Право та проблеми сталого розвитку в глобалізованому світі». Захід організовано Харківською обласною державною адміністрацією, Національною академією правових наук України, Національним юридичним університетом імені Ярослава Мудрого та за підтримки Агентства США з міжнародного розвитку (USAID) «Нове правосуддя» й Координатора проектів ОБСС в Україні.

У роботі Форуму взяли участь досвідчені політики, урядовці та науковці зі світовим ім'ям із Австрії, Бельгії, Білорусі, Болгарії, Великої Британії, Грузії, Данії, Естонії, Індії, Ірландії, Канади, Литви, Польщі, Словаччини, США, Туреччини, України, Німеччини, Чехії, Швейцарії, Швеції, співробіт- 